\title{
The spectre of educational policy spreads throughout Europe. Its presence as a discipline in postgraduate education
}

\author{
Alfredo Jiménez Eguizábal ${ }^{1, *}$, Carmen Palmero Cámara ${ }^{2}$, Isabel Luis Rico ${ }^{3}$ \\ 'Dpto. Ciencias de la Educación, Universidad de Burgos, Spain \{ajea@ubu.es\} \\ 2Dpto. Ciencias de la Educación, Universidad de Burgos, Spain \{cpalmero@ubu.es\} \\ 32Dpto. Ciencias de la Educación, Universidad de Burgos, Spain \{miluis@ubu.es\}
}

Received on 25 January 2013; revised on 31 January 2013; accepted on 14 March 2013; published on 15 July 2013

DOI: $10.7821 /$ naer.2.2.82-87

\begin{abstract}
The aim of this paper is to identify and analyse the ways educational policy is understood, taught and practiced as a training discipline at postgraduate level in the European context. We have validated its epistemological solvency through a quantitative, comparative and ethnographic study of its main features as a discipline -such as ideological and valorative component, praxis-oriented discourse or sustainable and plural normative proposals- found in a stratified sample of 20 countries, 112 universities and 170 training programmes. We also discuss the innovative and formative potential of educational policy to resolve the most contested pedagogical issues and design the educational system, specifying when, how and in which conditions it is constructed as an academic discipline. Among the findings stand out the accreditation and the assessment of the specific role of the values, actors, institutions, supranational decisions and public and curricular policies that shape up educational programmes at a European level, hence contributing to the disciplinary progress of educational policy as a pedagogical, normative, axiological and plural knowledge.
\end{abstract}

KEYWORDS: EDUCATIONAL POLICY, CURRICULUM, EPISTEMOLOGY, MASTERS DEGREES, DOCTORAL PROGRAMS

\section{OVERVIEW}

A specter is haunting Europe. We are turning to the metaphor used by Karl Marx (Die Frübschriften, Stuttgart, 1953) ready to verify some aspects of the anatomy of the educational policy ghost and to understand its itinerary. Will it be a failed attempt $a b$ initio- and a bold act pretending to outline the circumstantial keys to the different ways of understanding, teaching and practicing educational policy in the European context, as we intend to do in this study? Where does its special appeal lie?

In little over a decade, the Bologna Process has stimulated a shift in European universities, which is defined by its special concern about the formation of the new citizens. We are witnessing unforseen changes in the main hallmarks that define university education in its practical, discursive and sociopolitical dimensions (Nóvoa \& Lawn, 2002; Jiménez \& Palmero, 2007; Santos Rego, 2005).

Indeed, the implementation of the European Higher Education Area has led to a revision of university policies, and it is paying greater attention to objectives such as the rise of higher education competitiveness and the reinforcement of social cohesion in Europe (ENQA, 2009; Rauret, 2004). Among its implications, some of them not without criticism, we are particularly concerned with the changes that the progressive implementation of quality systems (EFQM, 2012) have caused in the academic offer. It is surprising how degree verification procedures have raised to the 'categoric imperative' level the inclusion into their processing of comparative data on similar qualifications and disciplines in other countries. The preliminary and preceptive favorable reports for the implementation of new academic offer depend to a great extent on these comparative data. A comparison with similar experiences is an unquestionable requirement for any teacher interested in the verification of university degrees, masters or doctorate programmes, which breaks traditional patterns in the sociogenesis of the academic offer as it involves a transnational and comparative approach.

Also, drawing the attention to educational policy becomes even more important for two reasons. On the one hand, we are dealing with a value-laden normative discipline, which requires a meticulous delimitation of its object and method. On the other hand, we are contributing to vindicate a public value and a recognized status that educational policy is yet to have. Its episteme and praxis are partly excluded from the decisionmaking process due to the distrust that a body of knowledge which is not yet considered to be definitely legitimated arises.

Some of these relevant issues have been discussed and have been the focus of research attention has been in the European context (Educational Policy Seminar, University of Valencia, Spain; http://www.uv.es/seminario-politica-educacion) and Latin America (Latin American Conference on Epistemological Studies in Educational Policy, Argentina, 2012; http://www.relepe.org/index.php/jornadas)

\footnotetext{
${ }^{*}$ To whom correspondence should be addressed:

Universidad de Burgos

Departamento de Ciencias de la Educación

Facultad de Humanidades y Educación

C/ Villadiego, s/n

09001 Burgos

Spain
} 


\section{MATERIALS AND METHODS}

Our objectives are defined through the intellectual practice of delving into the original sources. In order to structure our research we carried out an Internet search of academic offers, and we later contrasted the information gathered through telematic contacts and personal visits. This allowed us to gather the data on the presence of educational policy in master's and doctoral degrees, as well as its orientation and incidence in the general education program. Even though the data cannot be considered to be comprehensive, the information gathered may be sufficient to interpret the disciplinary configuration of educational policy.

The data analysed can be divided into two main blocks: a) One including all the institutional data, such as the type of university, strategic plan and degree specifications; b) A second one including the pedagogical and disciplinary information on curricula, modules, subjects, programmes and credits of the specific academic offers on educational policy.

The research methodology has been completed with the ethnographic and microinstitutional approach by visiting the centres in order to verify and define in objective terms their discourses and practices.

Table 1. Technical specifications of the study

\begin{tabular}{|c|c|}
\hline Fieldwork date & June-October 2012. \\
\hline Methodology & $\begin{array}{l}\text { Internet search. Ethnography: intentional } \\
\text { visits. }\end{array}$ \\
\hline \multirow{5}{*}{ Data collection tool } & Data registry. Structured form. \\
\hline & $\begin{array}{l}\text { a) Categorization data: University, type, } \\
\text { dimension, location, verification. }\end{array}$ \\
\hline & Academic organization: degree, \\
\hline & $\begin{array}{l}\text { curriculum, schedule, internal quality } \\
\text { control system. }\end{array}$ \\
\hline & $\begin{array}{l}\text { Educational Policy disciplinary features: } \\
\text { module, subject, guide, descriptors, } \\
\text { activities, bibliographical references. }\end{array}$ \\
\hline $\begin{array}{l}\text { Universe / } \\
\text { Population }\end{array}$ & European universities \\
\hline Sample & $\begin{array}{l}20 \text { Countries. } 112 \text { Universities. } 170 \\
\text { Programmes. Stratified. }\end{array}$ \\
\hline $\begin{array}{l}\text { Technical treatment } \\
\text { and analysis }\end{array}$ & $\begin{array}{l}\text { Software Data-Scan v5.5.5 to process the } \\
\text { form, SPSS } 18.0 \text { for the data processing }\end{array}$ \\
\hline Confidence level & $\begin{array}{l}\text { Over } 95 \% \text { for the general data (Finite } \\
\text { populations). }\end{array}$ \\
\hline
\end{tabular}

\section{ANALYSIS OF THE RESULTS AND DISCUSSION}

Some provisional results can be observed by analysing the areas of study in order to provide a coherent outlook of the presence of educational policy in postgraduate academic offers in Europe.

\section{1 'Merely moving blindly'. Building an interpretative community}

An objective survey of the academic offers shows an uninterrupted and relatively scattered thread of concepts and methodologies, which reflects the absence of a hermeneutic circle and of an interpretative community. This dispersion of approaches explains the inability to achieve a unique model of critical knowledge able to explain the problems that attain educational policy.
A question then arises. When it comes to the design of educational policy, why do we seem to be in a situation that Kant condemned in the field of metaphysics, constantly stuck, as if merely moving blindly?

Regardless of this, educational policy currently recognizes as its own the following areas of study:

- The epistemology and analysis of the complex nature of educational policy (Antunes, 2006; Jiménez, Jiménez, \& Palmero, 2006).

- The relationships between the state, law, society and education with significant legal and educational repercussions, emphasizing the right to education (Escudero, 2012; Dávila \& Naya, 2011; O’Hear, 2012).

- The study of power, legitimation mechanisms and modes of operation in education systems (Bonal \& Tarabini, 2006; Eurydice, 2008; Fernández Soria, 2007; Heimans, 2012; Viñao, 2002).

- Education as a public policy and educational administration as a goal-attainment-oriented techné. Education systems oriented towards excellence, development cooperation and education as public policy stand out. These are some of the teacher concerns which have developed in parallel with recent research studies that focus on these issues (García Ruiz, 2011; Griffiths, 2012; Martínez Usarralde, 2011; Manzanares \& Manzano-Soto, 2012).

- The settings and actors of political action in the educational systems. The focus is on the actors' behaviour in a globalization context (Luzón \& Sevilla, 2010; Rizvi \& Lingard, 2010; Tröhler, 2010) y de los grupos vulnerables (Demeuse \& Baye, 2008, Duru-Bellat, 2010; Mons, 2007).

- The explanation and criticism of the main democratization, socialization and political endoculturation processes in the different educational models (Aho, Pitkänen, \& Sahlberg, 2006; Biesta, 2010; OECD, 2012; Jover, López, \& Quiroga, 2011; Lingard, Creagh, \& Vass, 2012).

- The national and supranational educational decisions, especially regarding curriculum policy and the mechanisms that contribute to pedagogical regulation (Eurydice, 2011; Ferrer, 2012; Hopmann, Brinek, \& Retzl, 2007; Lingard \& Ozga, 2007; OECD, 2010; Pedró, 2012; Schleicher, 2006).

There are some interaction issues between very heterogeneous topics, in a sense common to other disciplines, and the strength of educational policy's academic offer depends on solving these problems. This objective need, which has recently been addressed in the $1^{\text {st }}$ Latin American Conference on Epistemological Studies in Educational Policy, organised by the Latin American Network of Epistemological Studies in Educational Policy, is particular urgent in the European Union as a consequence of the current financial and social crisis (Dehmel, 2006; Ertl, 2006; Grek, 2009; Lorente \& Torres, 2010; Nóvoa, 2010; Paricio, 2005; Valle, 2006; Vega Gil, 2011).

\subsection{Voices, echoes and silences}

Our portrayal of educational policy emerges from the data obtained after analysing the academic offers, but its assessment must be qualified taking into account the silences and omissions appreciated in the education proposals that avoid the study of power in education. Among them we can find the belief in 
education as something that should be left out of politics and of schools as non-political institutions. Some clarifying evidence that explains this omission is related to the aim of constructing a scientific reflection restricted to instrumental rationality and supported in alleged value neutrality.

\subsection{Rational deliberation and poiesis}

Democratic societies need to educate their members as free citizens, able to participate in the political deliberations and decisions. Freedom and involvement thus become meridians of the political activity and standards. In this sense, educational policy assumes the role of critically reviewing rational deliberation and education's poiesis, decisive for its contribution to the common good and for its influence in society renewal. Under these parameters, educational policy emerges as privileged perspective to study the schooling processes, as well as the non-formal and informal mechanisms of educational mediation, as reflected in the 'Master in Educational Innovation, Guidance Counselling and Evaluation' from the University of A Coruña in Spain, the 'Master in Inclusive Education' from the University of Kodolányi János in Hungary, in the 'Master in Educational Management and Administration' from the Université Catholique de 1'Ouest in France or in the 'Master in Educational Sciences' from the Eastern Mediterranean University in Cyprus.

\subsection{Assuming values}

Once we have overcome the epistemological positivism and recognised the axiological dimension of educational policy, we have to face the need to resolve the objectivity of a science riddled with values and realise how it is possible to take decisions on human purposes without adopting irrational stands. The main features of educational policy -its ideological and valorative component, praxis-oriented discourse or its sustainable and plural normative proposals- require constantly resorting to epistemological rationalism to justify educational policy as a pedagogical, normative, plural and axiological knowledge. Different insights on this view can be seen in the 'Master in Direction, Evaluation and Quality of Educational Institutions' from the University of Sevilla in Spain, in the 'Master in Globalisation and Educational Policy' from the University of Eastern Finland, in the 'Master in Pedagogical Sciences' from the University of Bari in Italy and the 'Master in Pedagogy' from the University of Rezekne in Latvia.

\subsection{The temporal surplus}

Similar considerations can be drawn about the time variable. There is a predominance of synchronic analyses of the political signifiers, although in some academic offers the diachronic dimension arises as a tool for conscience and elucidation of the actual historicity of power, showing that the most contested issues on educational policy are likely to get a favourable treatment when approached from a historical point of view, as can be seen in the 'Master in Politics, Administration and Management of Educational Organisations' from the University of Valencia in Spain, in the 'Master in Educational Sciences' from the University of Bologna in Italy or the 'Master in Education' from the University of London in the United Kingdom.

\subsection{No exclusions. Descriptions and explanations, norms and values}

We can differentiate, at least, two broad fields of study, increasingly interdependent. On the one hand, the field that focuses on political theories, a perspective that must remain vigilant to avoid falling into speculative sterility. And, on the other hand, a trend that addresses the concerns related to the construction of the suitable instruments, even experimental, that will allow us to understand political behaviour objectively. These days, mutually-exclusive approaches are not are not a possibility, so the European educational offer is both descriptive and explicative, while being also normative and valorative, as can be seen in the 'Master in Education Quality Management' from the Vytautas Magnus University in Lithuania, in the 'Education and International Development MA' from the University of London's Institute of Education in the United Kingdom, in the 'Master in Innovation and Education' from the University of Erfurt in Germany or in the 'MA in Educational Administration and Evaluation' from the University of Cyprus.

\subsection{Integrating antinomies}

The educational offer, far from regarding educational policy as mere cratology, addresses multiple dimensions of educational action: content, programmes, standards, coercive elements, social competences and interest groups. This involves the appearance of heterogeneous training models that oscillate between the margins of the more heuristically fertile antinomies of political science in general and of educational policy in particular.

\subsubsection{Institutional versus functional criteria}

Under this heading we are making reference to the doctrinal debate brilliantly discussed by the politologue David Easton (1953, 1965, 1969) regarding the use of institutional or functional criteria to define the object of political science, i.e., its identification with the study of the power of the state or, on the contrary, its equivalent in any power-related phenomenon. We should then note that educational policy allows us to get to know reality from two perspectives: regarding the structuring action of the state in education and also in terms of the dynamics of all sorts of power in the educational relationship. This is addressed in a supplementary way in the 'Master of Quality and Educational Improvement' from the Autonomous University of Madrid in Spain, in the 'Master Programme in Higher Education Administration and Management' from the University of Tampere in Finland, in the 'MEd in Inclusive Education' from the University of Manchester in the United Kingdom or in the 'Master in Primary Education' from the Catholic University in Ružomberok in Slovakia.

\subsubsection{Policy and politics}

As we know, there are two different terms in English to describe the different meanings of the Spanish term politica. The term 'policy', a transcription via Latin of the Greek noun politeia, meaning 'action program' or set of public authority measures, especially state-related, which try to achieve the aims of education; and the term 'politics', from the Greek politikós, which alludes to the ideological interests and values underlying power relations, with special attention to the discussions and disagreements that precede decision-making. Some programs that have tried to integrate this antinomy are the 'Euro-Latin American Master's Degree in Intercultural Education' from the 
National Distance Education University in Spain, the 'MA in Education and Social Pedagogy' from the University of Jena in Germany, the 'Professional Studies Master's Degree' from the Šiauliai University in Lithuania and the 'Master in Education' from Bath Spa University in the United Kingdom.

\subsection{The formalist legacy}

Formalism is the approach that has been used for the longest time in political science research. It identifies politics with the existing rules and institutions in a community, which explains its dependence on legal epistemology. In its application, we can differentiate two lines of action: an idiographic trend, which covers descriptive and changing research studies on the legal structure of the educational system and an educational political engineering trend which aims to act on the political mechanisms that manage schooling growth and control. Some representative examples are the 'Master in Education' from the National University of Ireland in Dublin, the 'Master in Educational Planning and Management' from the University of Veliko Tarnovo in Bulgaria and the 'MEd in Inclusive Education' from West Scotland University in the United Kingdom.

\subsection{The renovation of New Criticism}

Two positive remarks that can be made about the influence of this movement in the European education offer: the attention paid to power as an object and the autonomy achieved by educational policy, free from any sociological, historical or philosophical implication. In this power expansion are included some of the most particular traits of the utility and strategy research trend, which focuses on the development of a deductive model that explains and predicts the political-educational conducts. Such is the case of the 'Master in Educational Planning' from Sofia University in Bulgaria or the 'Master in Education' from the University of Oulu in Finland.

\subsection{Emotion, expressive systems and creativity}

The education offer also accommodates a perspective in which the events are organized from the point of view of the expressiveness of power. Affection-related elements become important in the analysis, and there is also an interest, from a genetic perspective, in analysing the expression developed by political actors. In any case, the interest lies in politics as energeia, as creation, a path that will also allow the development of theories of power, synchronous in nature, that focus on the particular examination of each policy. It also focuses on the principles that encourage trends open to new forms of culture and power, such as the educating city concept. This can be seen in the 'Master in Inclusive Education' from the University of Glasgow in the United Kingdom or in the 'Master in Education' from the University of Amsterdam in Holland.

\subsection{The changing presence of Marxist theories}

We refer to a group of critical methodologies which reinterpret society's contradictory behaviour through dialectics and historical relativism in an attempt to discover the consistency of Western culture's values. This Marxist criticism methodology is also present in some programmes that delve into the explanation of power from the actual way ideology operates, which conditions and regulates the production and reproduction frameworks. This can be seen in the 'School Improvement and Educational Leadership MA' from the University of
Birmingham or the 'Master in Education' from Cardiff Metropolitan University in the United Kingdom.

\subsection{Critical foundations of structuralism and narratology}

Structuralism, in as much as it represents, prima facie, a power analysis method, cannot remain in any way out of the formative purposes. Heterogeneous groups of materials -anthropological, political, social- are examined in order to clarify the rules that explain its operation as a system. Some immediate consequences of these analyses are the negation of history as a fact-organizing sequence and the annulment of the political actor's intentions.

We should also remember that one of the loose ends that formalism left - narratological analysis - gets to be tied again through structuralist discourse. This is reflected in the proposals that seek to identify the constituent elements of power through three levels of meaning: functions, action and narrative. Some efficient developments in this sense can be seen in the 'Master in Education' from the University of London in the United Kingdom, in the 'Master in Pedagogical Sciences' from the University of Modena and Reggio Emilia in Italy or the Pedagogy PhD from Karlstad University in Sweden.

\subsection{Generativism and predictability}

Surely one of the major research and training deficiencies in educational policy is the insufficient attention paid to the prospective dimension and possibilities of predictability. This lack has been partly resolved by a power analysing trend that emerged from the generative-transformational models initiated by Chomsky, which were very successful in linguistic analysis. With these roots, we are able to understand some of the education proposals in Europe which focus on predictability, such as the 'Master in Education Innovation Policies and Practices' from the University of Almeria in Spain, the 'Master in Sociology and Education Policy' from Tallinn University in Estonia or the 'Master in Inclusive Education' from the University of Glasgow in the United Kingdom.

\subsection{Communicative action and the pragmatic trail}

Postmodern approaches, by questioning the optimism illustrated in ability to use reason, led us to understand science through the pragmatic path, not just as instrumental rationality but also as an emancipatory activity in an open and democratic society. Some outstanding contributions on political action are derived from this approach, which is now oriented towards agreement and intersubjectivity.

In the analysis method, the communicative factors that condition power get involved with the pragmatics, and a theory of the acts of power hence emerges. In this vein, it becomes interesting to determine the reference axioms in the use of power which, in turn, become the basis of a fruitful analysis of its conventionality and universality. This is reflected in the 'Master in Education' from the Cardiff Metropolitan University in the United Kingdom, the 'Master in Education' from the National University of Ireland, and the 'MA in Children, Youth and International Development' from Brunel University in the United Kingdom.

\subsection{Discovering the recipients}

The discovery of reception opens up new development paths in the field of educational policy. The middle of the $20^{\text {th }}$ century 
was marked by the serious criticism of formalist models and the sociological interpretation of power, and rather focused on the role of the recipient as an active and participatory force of politics.

The consideration of social groups as recipients of political actions and the logic of collective action stand out among its important contributions, which has helped to reinterpret the educational modernization processes (see the initial contribution by Arthur Fisher Bentley: The Process of Government: A Study of Social Pressures, 1908. Chicago, University of Chicago Press). Such is the case of the 'Master in Organization and Educational Management' from the University of Thessaly in Greece, the 'Master in Education' from Daugavpils University in Latvia, the 'MA in Education, Policy \& Society' from King's College London and the 'MA in Global Development and Education' from the University of Leeds, both in the United Kingdom.

\subsection{The vitality and heterogeneity of hybridization}

It is hardly surprising to find hybrid traits in the planning of most formative offers in Europe if we take into account the complexity of educational policy, in which cognoscitive, practical and evaluative elements interact, including some deconstructionist traits that try to reread and even deny the foundations of culture. The hybridity of models prevails throughout.

Hybridity is not just a trend, and it does not imply an epistemological or methodological deviation either. It rather responds rather to the need to ground power in realistic contexts. Some interdisciplinary studies on power, community, culture and political socialization contribute to this. This hybridity and interdisciplinary collaboration is present masterfully in the 'Master of Research in Education, Cultural Diversity and Community Development' from the University of Santiago de Compostela in Spain, in the 'Master in Education Innovation Policies and Practices' from the University of Malaga in Spain, in the 'MA in Learning, Learning Environments and Educational Systems' from the University of Turku in Finland or the 'Master in Inclusive Education' from the University of Toulouse.

\section{CONCLUSIONS}

Through a critical analysis of educational policy in postgraduate education in the European context we have tried to show its epistemological reflexivity, specifying when, how and under what conditions it is constructed as an academic discipline.

The idea of complementarity emerges from the phenomenology analysed. This context of uncertainty, fragmentation and pluralism that characterizes the political experience raises this necessary convergence between objective, practical, dialogical and critical reasoning.

In an attempt to systematize, we can claim that the underlying rationale behind the academic offer in educational policy is based on the following basic premises:

a) The interest lies more in the organizational ability that shapes and structures education based on some coexistenceregulating values, rather than in the power that manages education through technical operations governed by instrumental rationality.

b) The connection between research and political and educational action is a necessary condition to make progress on our knowledge about the object and its validation, which makes creative functionality prevail over the productive dimension.

c) It is an eminently normative-practical reasoning, oriented towards rationalizing intervention sequences in the educational systems.

d) The reasoning behind educational policy is not confined to the deductive logic of applied science, but it involves ethical concerns as well.

e) It is considered an autonomous body of knowledge of an explicative and prescriptive nature, even though the complexity of the object of study makes it necessary to approach it from an interdisciplinary perspective.

Based on these assumptions, we can divide the current educational policy issues that need to be given a sensible response into three main blocks:

a) How the political-educational community is constituted from the point of view of its static structure.

b) How power operates in the dynamics of the educational process by analysing the factors that determine it and its regularities.

c) How education should be organized. In other words, projective criticism and the indictment of how the actors of educational policy should behave.

And, finally, once the previous issues had been tackled, a remodelling of the new and old knowledge fields -values, actors, institutions, curricular policies and supranational decisions (Puelles, 1999) - that characterize the educational offer at a European level should be addressed.

All of this makes us more aware of the need to increase the epistemological reflectivity levels that a scientific study of educational policy requires and to keep making progress, not without risks and uncertainties, in its construction and its reasonably creative and sustainable development as a discipline.

\section{REFERENCES}

Aho, E., Pitkänen, K., \& Sahlberg, P. (2006). Policy development and reform principles of Basic and Secondary Education in Finland since 1968. Washington: The World Bank.

Antunes, F. (2006). Globalisation and europeification of education policies: Routes, processes and metamorphoses. European Educational Research Journal, 5, 38-55. doi: 10.2304/eerj.2006.5.1.38

Biesta, G. (2010). How to exist politically and learn for it: Hanna Arendt and the problem of democratic education. Teacher College Record, $112(2), 556-575$.

Bonal, X. \& Tarabini, A. (2006). Globalización y política educativa: cambios de escala y consecuencias metodológicas. In L. M. Naya \& P. Dávila (Coords.). El derecho a la educación en un mundo globalizado (pp.125-137). Donosita: Erein.

Dávila, P. \& Naya, L. M. (Comps.) (2011). Derechos de la infancia y educación inclusiva en América Latina. Buenos Aires: Granica.

Dehmel, A. (2006). Making a European area of lifelong learning a reality? Some critical reflections on the European Union's lifelong learning policies. Comparative Education, 42 (1), 49-62. doi: 10.1080/03050060500515744

Demeuse, M. \& Baye, A. (2008). Mesurer et comparer l'équité des systèmes éducatifs en Europe. Education et Formations, 78, 137-148.

Duru-Bellat, A. M. (2010). Las desigualdades educativas en Europa: Una cuestión de actualidad. Revista Española de Educación Comparada, 16, 105-130.

Easton, D. (1953). The political system: An inquiry into the state of political change. New York: Alfred A. Knopf.

Easton, D. (1965). A Framework for Political Analysis. New Jersey: Prentice-Hall.

Easton, D. (1969). The new revolution in political science, American Political Science Review, 68(4), 1051-1061. doi: 10.2307/1955071 
European foundation for quality management (EFQM.) (2012). The Fundamental Concepts of Excellence. Retrieved from: http://www.efqm.org/Default.aspx?tabid=36

European association for quality assurance in higher education (ENQA). (2009). Standards and Guidelines for Quality Assurance in the European Higher Education Area. Retrieved from: http://www.enqa.eu/pubs.lasso

Ertl, H. (2006). European Union policies in education and training: the Lisbon agenda as a turning point?. Comparative Education, 42(1), 527. doi: $10.1080 / 03050060500515652$

Escudero, J. M. (2012). La educación inclusiva, una cuestión de derecho. Educatio. Siglo XXI, 30 (2), 109-128.

EURYDICE (2008). El gobierno de la Educación Superior en Europa. Politicas, estructuras, financiación y personal académico. Brussels: Education, Audiovisual \& Culture Executive Agency.

EURYDICE (2011). Science Education in Europe: National Policies, Practices and Research. Brussels: Education, Audiovisual \& Culture Executive Agency (EACEA P9 Eurydice).

Fernández Soria, J. M. (2007). Educar en valores. Formar ciudadanos. Vieja y nueva educación. Madrid: Biblioteca Nueva.

Ferrer, F. (2012). Presentation. Revista Española de Educación Comparada, 19, 11-16. Special issue dedicated to PISA: Contributions and impacts on national policies on education.

García Ruiz, M. J. (2011). Presentation. Revista Española de Educación Comparada, 18, 11-26. Special Issue on Excellent Educational Systems.

Grek, S. (2009). Governing by numbers: the PISA 'effect' in Europe. Journal of Education Policy, 24(1), 23-37. doi: $10.1080 / 02680930802412669$

Griffiths, M. (2012). Why joy in education is an issue for socially just policies. Journal of Education Policy, 27, 655-670. doi: 10.1080/02680939.2012.710019

Heimans, S. (2012). Education Policy, Practice and Power. Educational Policy, 26(3), 369-393. doi: 10.1177/0895904810397338

Hopmann, S. T., Brinek,G., \& Retzl, M. (Eds.) (2007). PISA zufolge PISA- PISA according to PISA. Vienna: Lit Verlag.

Jiménez, A., \& Palmero, C. (2007). New approaches to university in Spain: academic change, creative dimensions and ethical commitment in the establishment of the European Higher Education Area. Journal of Educational Administration and History, 39(3), 227-237. doi: 10.1080/00220620701536103

Jiménez, A., Jiménez, J., \& Palmero, C. (2006). La política educativa y la naturaleza compleja de la educación. Nuevos enfoques epistemológicos. Revista Española de Pedagogía, 234, 249-272.

Jover, G., López, E., \& Quiroga, P. (2011). La participación política de los estudiantes en la Universidad. In A. Ariño \& R. Llopis (Eds.). ¿Universidad sin clases? Condiciones de vida de los estudiantes universitarios en España (Eurostudent IV) (pp. 233-252). Madrid: Ministerio de Educación.

Latin American Conference on Epistemological Studies in Educational Policy (2012). Argentina. Retrieved from http://www.relepe.org/index.php/jornadas

Jover, G., López, E., \& Quiroga, P. (2011). La participación política de los estudiantes en la Universidad. In A. Ariño \& R. Llopis (Eds.). ¿Universidad sin clases? Condiciones de vida de los estudiantes universitarios en España (Eurostudent IV) (pp. 233-252). Madrid: Ministerio de Educación.

Lingard, B. \& Ozga, J. (Eds.) (2007). The Routledge Reader in Education Policy and Politics. London: Routledge.

Lingard, B., Creagh, S., \& Vass, G. (2012). Education policy as numbers: Data categories and two Australian cases of misrecognition, Journal of Education Policy, 27, 315-333. doi: $10.1080 / 02680939.2011 .605476$

Lorente, R. \& Torres, M. (2010). Políticas de educación y formación en la Unión Europea: Una historia de cambios y continuidades, Revista Española de Educación Comparada, 16, 159-183.

Luzón, A. \& Sevilla, D. (2010). Presentation. La Agenda de Lisboa en el proceso de construcción europea, Revista Española de Educación Comparada, 16, 15-21. Special Issue about the Program 2010 on the concrete future objectives of education systems in the European Union.

Manzanares, A. \& Manzano-Soto, N. (2012). Presentation, Revista de Educación. 14-20. Special Issue on public policies on education support and remedial education.

Martínez Usarralde, M. J. (Coord.) (2011). Presentation, Revista Española de Educación Comparada, 17, 11-30. Special Issue on cooperation in relation to development in education: Alliances in comparative education according to the developmental approach.

Mons, N. (2007). Les nouvelles politiques éducatives. Paris: PUF.

Nóvoa, A. (2010). La construcción de un espacio educativo europeo: gobernando a través de los datos y la comparación, Revista Española de Educación Comparada, 16, 23-41.

Nóvoa, A. \& Lawn, M. (2002). Fabricating Europe. The Formation of an Education Space. Netherlands: Kluwer Academic Publishers. doi: 10.1007/0-306-47561-8

O'Hear, A. (2012). Education and the modern state, Social Philosophy and Policy, 29(1), 322-335. doi: 10.1017/S0265052511000100

OECD (2010). PISA 2009 Results:What makes a school successful? Resources, policies and practices. Paris: OECD. doi: 10.1787/9789264091559-en

OECD (2012). Education at a Glance 2012. Paris: OECD.

Paricio, M. S. (2005). Política Educativa Europea, Revista de Educación, $337,251-278$

Pedró, F. (2012). Deconstruyendo los puentes de PISA: del análisis de resultados a la prescripción política. Revista Española de Educación Comparada, 19, 139-171.

Puelles, M. (1999). Política de la educación: viejos y nuevos campos de conocimientos. Revista de Ciencias de la Educación, 178-179, 187208.

Rauret, G. (2004). La acreditación en Europa. Revista interuniversitaria de formación del profesorado, 49, 131-147.

Rizvi, F. \& Lingard, B. (2010). Globalizing education policy. London: Routledge.

Santos Rego, M. A. (2005). La Universidad ante el proceso de convergencia europea: Un desafío de calidad para la Unión Europea, Revista Española de Pedagogía, 230, 5-16.

Seminar on Educational Policy (15th and 16th November 2012). University of Valencia. Retrieved from http://www.uv.es/uvweb/departament educacio comparada historia _educacio/ca/seminari-politica-educacio/presentacio$\overline{1} 285862003655 . \mathrm{html}$

Schleicher, A. (2006). Fundamentos y cuestiones políticas subyacentes al desarrollo de PISA. Revista de Educación. Special Issue on PISA, $21-43$.

Tröhler, D. (2010). Harmonizing the Educational Globe. World Polity, Cultural Features, and the Challenges to Educational Research, Studies in Philosophy and Education, 29(1), 5-17. doi: 10.1007/s11217-009-9155-1

Valle, J. M. (2006). La Unión Europea y su política educativa. Madrid: Ministerio de Educación y Ciencia, Centro de Investigación y Documentación Educativa.

Vega Gil, L. (2011). Gobernanza y políticas de formación inicial de profesores en la Europa mediterránea. Valencia: Tirant Lo Blanch.

Viñao, A. (2002). Do Education Reforms Fail? A Historian's Response. Encounters on Education, 2, 27-47.

\section{ACKNOWLEDGMENT}

This article is framed within the non-guided fundamental research project subprogramme of the Spanish Ministry of Economy and Competitiveness De los tiempos educativos a los tiempos sociales: La construcción cotidiana de la condición juvenil en una sociedad de redes. Problemáticas especificas y alternativas pedagógico-sociales (coordinated project EDU2012-39080-C07-00) and to the subproject De los tiempos educativos a los tiempos sociales: Impacto de la educación en la red de emprendimiento en los Jóvenes. Competencias e Innovaciones curriculares (Reference EDU 2012-39080-C0706), funded under the Spanish National R\&D Plan with a grant from the Spanish Ministry of Economy and Competitiveness and the European Regional Development Fund (ERDF , 2007-2013). 